\title{
Identification of diverse groundnut germplasm: Sources of early maturity in a core collection
}

\author{
Hari D. Upadhyaya *, L.J. Reddy, C.L.L. Gowda, Sube Singh \\ Crop Improvement, International Crops Research Institute for the Semi-Arid Tropics (ICRISAT), \\ P.O. Patancheru 502324, Andhra Pradesh, India
}

Received 16 May 2005; received in revised form 10 October 2005; accepted 17 October 2005

\begin{abstract}
A groundnut core collection was evaluated in two seasons to identify 21 early maturing landraces. Phenotypic diversity of these 21 early maturing landraces was assessed in three rainy and five post-rainy seasons, along with the three known sources of early maturity (Chico, Gangapuri, and JL 24). The new sources differed in 8 of 14 morphological traits studied. Of the 14 agronomic and 2 quality traits studied, 8 yield and yield-component traits were evaluated at two harvest dates. The landraces matured in 80-90 days after sowing (DAS), similar to Chico and Gangapuri (80-90 DAS) and earlier than JL 24 (90-95 DAS). Four new early maturing landraces [ICG 4558 (India); ICG 4890 (Argentina); ICG 9930 (Zimbabwe); ICG 11605 (Bolivia)], with predominantly three to four seeds per pod, were identified as additional sources for breeding confectionery groundnut varieties. Correlation coefficients between the observations made at the two harvest dates for the seven yield traits were $\geq 0.71$, indicating a single observation is sufficient at 75 DAS or 90 DAS in initial characterization. Correlation between pod yield and 100-seed weight was significant in all the eight seasons individually and overall at 90 DAS. Presence of additional phenotypic diversity in the new early maturity landraces was detected. Principal component analysis (PCA) using the first 10 PC scores delineated the 21 landraces into three clusters. The formation of these clusters could neither be explained on the basis of geographic areas of landraces collection nor on the basis of botanical varieties. This might reflect the nascent variation acquired by the landraces in their secondary habitats, under ecologically similar conditions, independent of their countries of origin. Landraces in clusters 2 and 3 showed a wide range for several agronomic traits, indicating their usefulness in breeding programs for developing early maturing high yielding broad based cultivars. (C) 2006 Elsevier B.V. All rights reserved.
\end{abstract}

Keywords: Core collection; Diversity assessment; Early maturity; Groundnut landraces; Principal component analysis

\section{Introduction}

Groundnut (Arachis hypogaea L.) is an annual legume, grown primarily for high quality edible oil and easily digestible protein in its seeds. It is cultivated in 109 countries, in tropical, sub-tropical, and warm temperate regions of the world. During 2003 it was grown on 26.46 million ha with an estimated total production of 35.66 million $\mathrm{t}$ (groundnuts in shell) and an average productivity of $1.35 \mathrm{t} \mathrm{ha}^{-1}$ (FAO, 2004). Over two-thirds of global groundnut production occurs in seasonally dry regions, where drought is a potential constraint for crop

\footnotetext{
* Corresponding author. Tel.: +91 403071 3333; fax: +91 4030713074 .

E-mail address: h.upadhyaya@ cgiar.org (H.D. Upadhyaya).
}

production (Smartt, 1994). Average groundnut yield is about $0.8 \mathrm{tha}^{-1}$ in the Semi-Arid Tropical (SAT) countries, which is lower than the world average (1.35 $\mathrm{t} \mathrm{ha}^{-1}$ during 2003). Besides the occurrence of pests and diseases and poor socioeconomic conditions of SAT farmers, lack of adapted varieties matching the available crop duration, contribute towards poor yields in the SAT.

Early maturing groundnut cultivars with improved yield are required for several agro-ecological situations. Such situations include short growing seasons, necessitated by end-of-season droughts, cooler temperatures, and early frosts. Early maturing cultivars also form an important component of high intensity multiple cropping systems in South and Southeast Asia (Gibbons, 1980). Such cropping systems involving early maturing cultivars, either as inter or 
as sequence crops provide opportunities to the resource-poor farmers to minimize the risk of crop failures and problems of soil health. They also allow cultivation of more crops, resulting in higher per day productivity, and gainful employment to farm labor for an extended period. Short growing seasons, such as those that occur in the semi-arid regions prevent groundnut from maturing properly. Immature pods lower groundnut quality and yield, and enhance the growth of toxin-producing molds during storage (N'Doye and Smith, 1993). Hence, breeding early maturing high yielding groundnut varieties is an important objective in many breeding programs in the world.

Most groundnut improvement programs have so far used only a few germplasm sources for early maturity. They include Chico, Gangapuri, and JL 24 (Upadhyaya et al., 2001b). Chico is an early maturing Spanish (subsp. fastigiata var. vulgaris) germplasm line (Bailey and Hammons, 1975). Gangapuri (Ramamurthy, 1974) and JL 24 (Patil et al., 1980) are early maturing cultivars grown in India. The former belongs to subsp. fastigiata var. fastigiata and the latter belongs to subsp. fastigiata var. vulgaris. Chico is the most extensively used source of earliness in several breeding programs. It has been used 1180 times as a parent in developing early maturity lines at ICRISAT from 1976 to 2002 (Upadhyaya, unpublished). This has resulted in a narrow base of cultivars developed in these programs. The currently used early maturity sources have some defects, Chico with short stature, low biomass, and very small pods (Bailey and Hammons, 1975), and Gangapuri with low shelling percentage and low harvest index (Ramachandran et al., 1980). Hence, there is a need to identify additional sources of early maturity for use in breeding programs. In the past, global groundnut germplasm has not been systematically evaluated for the identification of early maturing genotypes due to the requirement of huge resources for testing the large number of accessions. To overcome this problem in groundnut, Upadhyaya et al. (2003) developed a representative core collection consisting of 1704 accessions from 14,310 accessions in the ICRISAT genebank. The core collections in groundnut have previously been used successfully in identification of resistance sources to various diseases (Anderson et al., 1996; Franke et al., 1999; Holbrook and Anderson, 1995; Isleib et al., 1995), drought tolerance traits (Upadhyaya, 2005) and other traits such as high oil content (Holbrook et al., 1998), and cold tolerance (Upadhyaya et al., 2001a). The main objectives of this study were to identify new early maturing germplasm sources in a groundnut core collection and assess their diversity in various traits at two harvest dates based on the cumulative thermal time (measured as degree days, ${ }^{\circ} \mathrm{Cd}$ ).

\section{Materials and methods}

A groundnut core collection comprising 1704 germplasm accessions was planted in an augmented design using four control cultivars, ICGS 44, ICGS 76, M 13, and Gangapuri to identify early maturing sources in the 1999 rainy season. Each entry was planted on a $4 \mathrm{~m}$ long ridge in a ridge-furrow system. The spacing was $60 \mathrm{~cm}$ between ridges and $10 \mathrm{~cm}$ between plants in subsp. fastigiata and $15 \mathrm{~cm}$ in subsp. hypogaea on a ridge. Botanical variety-specific control cultivars were repeated after every nine test entries. These include ICGS 44 (PI 537112), a Spanish cultivar, released from ICRISAT; ICGS 76 (PI 546372), a Virginia cultivar (subsp. hypogaea var. hypogaea), released from ICRISAT; M 13, an old Virginia runner cultivar released in India and Gangapuri an early maturing (80-90 DAS) Valencia (fastigiata) cultivar from India (Ramamurthy, 1974). At $1470{ }^{\circ} \mathrm{Cd}$ (equivalent to $90 \mathrm{DAS}$ in the rainy season at ICRISAT Center, Patancheru) (Rao et al., 1992), half of the plot was harvested to assess maturity. None of the genotypes belonging to subspecies hypogaea showed early maturity and only 14 vulgaris and 5 fastigiata landraces from 13 countries showed maturity similar to Gangapuri. We selected these landraces and evaluated them in a preliminary trail in the 1999-2000 post-rainy season at two harvest dates $1240{ }^{\circ} \mathrm{Cd}$ (equivalent to $75 \mathrm{DAS}$ in the rainy season at ICRISAT Center, Patancheru) and at $1470{ }^{\circ} \mathrm{Cd}$ at ICRISAT Center, Patancheru, India. In the 1999-2000 post-rainy season, we selected additional 17 vulgaris and 5 fastigiata early maturing landraces of 15 countries from the groundnut core collection. We evaluated them separately in another trial at $1240{ }^{\circ} \mathrm{Cd}$ and $1470{ }^{\circ} \mathrm{Cd}$ during the 2000 rainy season at ICRISAT Center, Patancheru. Considering pod yield, shelling percentage, and 100-seed weight at both harvests, 21 (17 vulgaris and 4 fastigiata) promising landraces (14 from first trial and 7 from second trial), were selected for further evaluation.

The 21 chosen landraces were evaluated during three rainy and five post-rainy seasons. The details on the origin and botanical type of the landraces studied are given in Table 1. All the 21 landraces and the three controls belong to the subspecies fastigiata (Krapovickas and Gregory, 1994). Four accessions (ICG 4558, ICG 4890, ICG 9930, and ICG $11605)$ belong to the variety fastigiata and the remaining belong to variety vulgaris. Information on number of replications, plot size, and the details of traits recorded in different seasons is given in Table 2 . In all seasons, we adopted a plot size of $6 \mathrm{~m}^{2}(4 \mathrm{~m} \times 1.5 \mathrm{~m}$ broad bed comprising four rows), a row to row spacing of $30 \mathrm{~cm}$ and a plant to plant spacing of $10 \mathrm{~cm}$ within a row, and normal plant protection and irrigation practices. For each harvesting date half of the plot $(2 \mathrm{~m} \times 1.5 \mathrm{~m}$ broad bed comprising four rows) was used to record various observations. The performance of the landraces was assessed by using cumulative thermal time expressed as ${ }^{\circ} \mathrm{Cd}$ (Rao et al., 1992) and were harvested when the crops were exposed to $1240{ }^{\circ} \mathrm{Cd}$ and $1470{ }^{\circ} \mathrm{Cd}$ in randomized complete block design using two or three replications (Table 2). Fourteen morphological traits were recorded on plot basis on all the 21 landraces and 3 control cultivars, following IBPGR/ 
Table 1

Information on origin and botanical type of early maturity groundnut landraces used in the study

\begin{tabular}{llll}
\hline Genotype & Synonym & Botanical variety & Origin \\
\hline ICG 3200 & EC 16669 & Vulgaris & China \\
ICG 3540 & You ka Ich & Vulgaris & China \\
ICG 3631 & EC 109276 & Vulgaris & Zaire \\
ICG 4558 & IC 22942 & Fastigiata & India \\
ICG 4729 & Worte sutuei & Vulgaris & China \\
ICG 4890 & AH 7081 & Fastigiata & Argentina \\
ICG 5512 & AH 7778 & Vulgaris & India \\
ICG 5560 & AH 7844 & Vulgaris & India \\
ICG 5881 & VRR 115 & Vulgaris & India \\
ICG 9427 & 63-111 & Vulgaris & Senegal \\
ICG 9930 & RV 5 & Fastigiata & Zimbabwe \\
ICG 9968 & 57-386-1 & Vulgaris & Sudan \\
ICG 11605 & PI 475919 & Fastigiata & Bolivia \\
ICG 11914 & RS $44-3$ & Vulgaris & Mali \\
ICG 13585 & SSI 5 & Vulgaris & Indonesia \\
ICG 13606 & SSI 33 & Vulgaris & Indonesia \\
ICG 13647 & SSI 20 & Vulgaris & Indonesia \\
ICG 14390 & SNW 47 & Vulgaris & Myanmar \\
ICG 14788 & SKN 2 & Vulgaris & Vietnam \\
ICG 14814 & SKN 29 & Vulgaris & Vietnam \\
ICG 14815 & SKN 30 & Vulgaris & Vietnam \\
Controls & & & \\
ICG 7827 & JL 24 & Vulgaris & India \\
ICG 476 & Chico & Vulgaris & USSR \\
ICG 2738 & Gangapuri & Fastigiata & India \\
\hline
\end{tabular}

ICRISAT (1992). Observations were also recorded for 14 agronomic traits and for oil and protein content in seeds either on plant or plot basis both in rainy and post-rainy seasons. However, observations on all the traits were not recorded in all the seasons.

Days to emergence (the stage when 50\% seedlings have emerged), days to $50 \%$ flowering (days from emergence to the stage when $50 \%$ plants have begun flowering) were recorded on plot basis. Plant height, leaflet length, and width on five competitive plants were recorded at 60 days from sowing in the rainy seasons and at an equivalent cumulative thermal time $\left(1000^{\circ} \mathrm{Cd}\right)$ in the post-rainy seasons. Pods per plant, pod length and width, seed length and width, 100-seed weight, and shelling percentage, were recorded at 75 DAS $\left(1240{ }^{\circ} \mathrm{Cd}\right)$ and $90 \mathrm{DAS}\left(1470{ }^{\circ} \mathrm{Cd}\right)$. Pods per plant were calculated from five competitive plants. Pod length and width were recorded on 10 mature pods and seed length and width on 10 mature seeds. Two-hundred-gram sound mature pods were used to calculate shelling percentage. Sound seeds were used to record 100-seed weight and for oil and protein estimates. Oil content was measured with a commercial nuclear magnetic resonance spectrometer following the procedure described by Jambunathan et al. (1985) and protein content was estimated with a Technicon Autoanalyser (Pulse Instrumentation Ltd., Saskatoon, SK; Singh and Jambunathan, 1980). Pod yields were uniformly converted to $\mathrm{kg} \mathrm{ha}^{-1}$ for comparison across the seasons.

Data were analyzed following residual maximum likelihood (REML) analysis using seasons as fixed and entries as
Table 2

Details of replicated experiments conducted to evaluate early maturity groundnut landraces at ICRISAT Center, Patancheru, India

\begin{tabular}{|c|c|c|c|}
\hline Season & $\begin{array}{l}\text { Number of } \\
\text { replications }\end{array}$ & $\begin{array}{l}\text { Plot } \\
\text { size }\left(m^{2}\right)\end{array}$ & Quantitative traits ${ }^{\mathrm{a}}$ \\
\hline $\begin{array}{l}\text { 1999-2000 } \\
\text { post-rainy }\end{array}$ & 2 & 6 & $\begin{array}{l}\text { EMR, DF, LLN, LWD, } \\
\text { PLHT, PRBR, PPP } \\
\text { PLN }^{\mathrm{b}}, \mathrm{PWD}^{\mathrm{b}}, \mathrm{SLN}^{\mathrm{b}}, \mathrm{SWD}^{\mathrm{b}} \text {, } \\
\text { PYKGH }^{\mathrm{b}}, \mathrm{SH}^{\mathrm{b}}, \mathrm{SDWT}^{2}\end{array}$ \\
\hline 2000 rainy & 3 & 6 & $\begin{array}{l}\text { EMR, DF, LLN, LWD, } \\
\text { PLHT, PRBR, PPP, } \\
\text { PLN, PWD, SLN, } \\
\text { SWD, PYKGH, } \\
\text { SH\%, SDWT }\end{array}$ \\
\hline $\begin{array}{l}\text { 2000-2001 } \\
\text { post-rainy }\end{array}$ & 3 & 6 & $\begin{array}{l}\text { EMR, DF, LLN, } \\
\text { LWD, PLHT, PRBR, } \\
\text { PPP, PLN, PWD, } \\
\text { SLN, SWD, PYKGH, } \\
\text { SH\%, SDWT }\end{array}$ \\
\hline 2001 rainy & 2 & 6 & DF, PYKGH, SH\%, SDWT \\
\hline $\begin{array}{l}\text { 2001-2002 } \\
\text { post-rainy }\end{array}$ & 2 & 6 & $\begin{array}{l}\text { DF, PYKGH, SH\%, } \\
\text { SDWT, OIL } \%, \text { PROT\% }\end{array}$ \\
\hline $\begin{array}{l}2002-2003 \\
\text { post-rainy }\end{array}$ & 2 & 6 & $\begin{array}{l}\text { DF, PYKGH, SH\%, } \\
\text { SDWT, OIL\% }\end{array}$ \\
\hline 2003 rainy & 2 & 6 & DF, PYKGH, SH\%, SDWT \\
\hline $\begin{array}{l}\text { 2003-2004 } \\
\text { post-rainy }\end{array}$ & 2 & 6 & $\begin{array}{l}\text { DF, PYKGH, SH\%, } \\
\text { SDWT, OIL\% }\end{array}$ \\
\hline
\end{tabular}

EMR: days to $50 \%$ emergence, DF: days to $50 \%$ flowering, LLN: leaflet length (mm), LWD: leaflet width (mm), PLHT: plant height $(\mathrm{cm})$, PRBR: primary branch (no.), PPP: pod per plant (no.), PLN: pod length $(\mathrm{mm})$, PWD: pod width (mm), SLN: seed length (mm), SWD: seed width $(\mathrm{mm})$, PYKGH: pod yield $\left(\mathrm{kg} \mathrm{ha}^{-1}\right), \mathrm{SH} \%$ : shelling percentage, SDWT: 100-seed weight (g), OIL\%: oil content (\%), and PROT: protein content $(\%)$.

${ }^{b}$ Data recorded at both harvest dates $\left(1240{ }^{\circ} \mathrm{Cd}\right.$ and $\left.1470{ }^{\circ} \mathrm{Cd}\right)$.

random on GENSTAT 6.1. The season component was divided into rainy and post-rainy and their interactions with genotypes were determined. In all the subsequent analyses, genotype $\times$ season interaction was considered and if it was significant for a trait the separate values were considered for each season and if it was non-significant, then mean values over seasons were used. The correlations for yield and yield related traits were calculated separately for the two harvest dates using best linear unbiased predictors (BLUPs) for all the agronomic traits studied. The component of phenotypic variance $\left(\delta^{2} p\right)$ due to genotype $\left(\delta^{2} g\right)$, genotype $\times$ environenvironment $\left(\delta^{2} g e\right)$, and residual and their standard errors were calculated.

Principal component analysis (PCA) was carried out using standardized data. The mean observations of all traits for each season were standardized by subtracting from each observation the mean value of the character and subsequently dividing by its respective standard deviation. The resulting standardized values for each trait had an average of 0 and standard deviation of 1 or less. The PCA was performed using GENSTAT 6.1. Cluster analysis according to Ward (1963) was performed using scores of first 10 principal components, resulting in three clusters. The means of each trait in different clusters were compared using Newman-Keuls test (Newman, 1939; Keuls, 1952). The 
homogeneity of variances among the clusters was tested using Levene's test (Levene, 1960).

A phenotypic distance matrix was created by calculating the differences between each pair of entries for each characteristic. The diversity index was calculated by averaging all the differences in the phenotypic values for each trait divided by respective range (Johns et al., 1997).

\section{Results and discussion}

All of the 21 early maturity landraces studied were similar in their erect growth habit, sequential branching pattern, almost with glabrous surface on both sides of leaflet, flowers with dark orange streak color, presence of peg color, and one seed color pattern (data not shown). The landraces differed, however, in their plant pigmentation, stem hairiness, leaf color, pod beak, pod constriction and reticulation, seeds per pod, and primary seed color (Table 3). For stem hairiness, they were sub-glabrous to moderately hairy. All the landraces had light green leaflets, except ICG 11914, with green leaflets. Pod beaks varied from prominent to slight, pod constriction from slight to none, and pod reticulation from prominent to slight. Seeds per pod varied from 1 to 4 . While, most landraces had predominantly two-seeded pods, four of them ICG 4558 (India), ICG 4890 (Argentina), ICG 9930 (Zimbabwe), and ICG 11605 (Bolivia) in addition to the control variety, Gangapuri (ICG 2738), had predominantly three-seeded pods and some four-seeded pods. Gangapuri is the most preferred variety for in-shell boiled and roasted nuts in India because it produces more seeds per pod. Similar to Gangapuri, all the four new early maturity sources belong to the botanical variety fastigiata. However, they differ among themselves and with Gangapuri in stem hairiness, pod constriction, and primary seed color (Table 3). These four newly identified landraces, which originated in different countries, may provide useful genetic variability in breeding programs aimed at developing short-duration groundnut varieties.

Estimates of variance due to genotype, season $\times$ genotype, and their standard error and Wald statistics and Chi-square probability for various traits during three rainy and five post-rainy seasons at ICRISAT Center, Patancheru, India, are given in Table 4.

Table 3

Morphological variation ${ }^{\mathrm{a}}$ in the newly identified early maturity sources in groundnut

\begin{tabular}{|c|c|c|c|c|c|c|c|}
\hline Genotype & $\begin{array}{l}\text { Plant } \\
\text { pigmentation }\end{array}$ & Stem hairiness & $\begin{array}{l}\text { Pod } \\
\text { beak }\end{array}$ & $\begin{array}{l}\text { Pod } \\
\text { constriction }\end{array}$ & $\begin{array}{l}\text { Pod } \\
\text { reticulation }\end{array}$ & $\begin{array}{l}\text { Seeds } \\
\text { per pod }\end{array}$ & $\begin{array}{l}\text { Primary } \\
\text { seed color }\end{array}$ \\
\hline ICG 3200 & Absent & Sub-glabrous, hairs in 1 or 2 rows along main axis & Moderate & Moderate & Prominent & $2-1$ & Tan \\
\hline ICG 3540 & Absent & Sub-glabrous, hairs in 1 or 2 rows along main axis & Slight & Moderate & Moderate & $2-1$ & Tan \\
\hline ICG 3631 & Present & Sub-glabrous, hairs in 1 or 2 rows along main axis & Slight & Slight & Moderate & $2-1$ & Red \\
\hline ICG 4558 & Present & $\begin{array}{l}\text { Moderately hairy, hairs in } 3 \text { or } 4 \text { rows along } \\
\text { main axis }\end{array}$ & Slight & Slight & Slight & $\begin{array}{l}3-2-4-1 / 3- \\
2-1-4 / 3-4-2-1\end{array}$ & Red \\
\hline ICG 4729 & Absent & Sub-glabrous, hairs in 1 or 2 rows along main axis & Slight & Moderate & Slight & $2-1$ & Tan \\
\hline ICG 4890 & Absent & Sub-glabrous, hairs in 1 or 2 rows along main axis & Slight & Slight & Slight & $\begin{array}{l}3-2-4-1 / 3-2-1- \\
4 / 3-4-2-1\end{array}$ & Dark purple \\
\hline ICG 5512 & Absent & Sub-glabrous, hairs in 1 or 2 rows along main axis & Slight & Moderate & Slight & $2-1$ & Tan \\
\hline ICG 5560 & Absent & Sub-glabrous, hairs in 1 or 2 rows along main axis & Slight & Moderate & Slight & $2-1$ & Tan \\
\hline ICG 5881 & Absent & Sub-glabrous, hairs in 1 or 2 rows along main axis & Slight & Moderate & Slight & $2-1$ & Tan \\
\hline ICG 9427 & Absent & Sub-glabrous, hairs in 1 or 2 rows along main axis & Moderate & Slight & Slight & $2-1$ & Dark tan \\
\hline ICG 9930 & Present & Moderately hairy, hairs in 3 or 4 rows along main axis & Slight & Slight & Slight & $\begin{array}{l}3-2-4-1 / 3-2- \\
1-4 / 3-4-2-1\end{array}$ & Red \\
\hline ICG 9968 & Present & Sub-glabrous, hairs in 1 or 2 rows along main axis & Moderate & Moderate & Moderate & $2-1$ & Red \\
\hline ICG 11605 & Present & Moderately hairy, hairs in 3 or 4 rows along main axis & Slight & None & Slight & $\begin{array}{l}3-2-4-1 / 3-2- \\
1-4 / 3-4-2-1\end{array}$ & $\begin{array}{l}\text { Purplish- } \\
\text { red/reddish- } \\
\text { purple }\end{array}$ \\
\hline ICG $11914^{\mathrm{b}}$ & Present & Moderately hairy, hairs in 3 or 4 rows along main axis & Slight & Moderate & Moderate & $2-1$ & Tan \\
\hline ICG 13585 & Present & Sub-glabrous, hairs in 1 or 2 rows along main axis & Moderate & Moderate & Slight & $2-1$ & Tan \\
\hline ICG 13606 & Present & Sub-glabrous, hairs in 1 or 2 rows along main axis & Slight & Moderate & Moderate & $2-1$ & Tan \\
\hline ICG 13647 & Present & Moderately hairy, hairs in 3 or 4 rows along main axis & Moderate & Moderate & Moderate & $2-3-1 / 2-1-3$ & Tan \\
\hline ICG 14390 & Absent & Sub-glabrous, hairs in 1 or 2 rows along main axis & Slight & Slight & Moderate & $2-1$ & Tan \\
\hline ICG 14788 & Absent & Sub-glabrous, hairs in 1 or 2 rows along main axis & Moderate & Slight & Moderate & $2-1$ & Light tan \\
\hline ICG 14814 & Absent & Sub-glabrous, hairs in 1 or 2 rows along main axis & Moderate & Slight & Moderate & $2-1$ & Tan \\
\hline ICG 14815 & Absent & Sub-glabrous, hairs in 1 or 2 rows along main axis & Moderate & Moderate & Moderate & $2-3-1 / 2-1-3$ & Tan \\
\hline \multicolumn{8}{|l|}{ Controls } \\
\hline JL 24 & Absent & Sub-glabrous, hairs in 1 or 2 rows along main axis & Moderate & Moderate & None & $2-1$ & Dark tan \\
\hline Chico & Absent & Sub-glabrous, hairs in 1 or 2 rows along main axis & Prominent & Moderate & Slight & $2-1$ & Tan \\
\hline Gangapuri & Present & Sub-glabrous, hairs in 1 or 2 rows along main axis & Slight & Slight & Slight & $\begin{array}{l}3-2-4-1 / 3-2- \\
1-4 / 3-4-2-1\end{array}$ & Red \\
\hline
\end{tabular}

\footnotetext{
${ }^{a}$ No variation was observed among the early maturity landraces for growth habit, branching pattern, leaflet surface hairiness, color of standard petal markings, peg color, and seed color pattern.

${ }^{\mathrm{b}}$ Except ICG 11914 with green leaf color, the rest of the landraces have light green leaves.
} 
Table 4

Estimates of variance due to genotype, genotype $\times$ season, standard error Wald statistic, and $\chi^{2}$ probability for groundnut landraces evaluated during three rainy and five post-rainy seasons in two harvests at ICRISAT Center, Patancheru, India

\begin{tabular}{|c|c|c|c|c|c|c|c|c|c|c|c|c|c|c|c|c|c|}
\hline \multirow[t]{2}{*}{ Trait } & \multicolumn{9}{|l|}{ Variance } & \multicolumn{8}{|c|}{ Wald statistic } \\
\hline & $\begin{array}{l}\text { Number } \\
\text { of seasons }\end{array}$ & Genotype & S.E. & $\begin{array}{l}\text { Genotype } \\
\times \text { season }\end{array}$ & S.E. & $\begin{array}{l}\text { Genotype } \\
\times \text { post-rainy }\end{array}$ & S.E. & $\begin{array}{l}\text { Genotype } \\
\times \text { rainy }\end{array}$ & S.E. & Seasons & $\begin{array}{l}\chi^{2} \\
\text { prob. }\end{array}$ & $\begin{array}{l}\text { Post-rainy } \\
\text { season }\end{array}$ & $\begin{array}{l}\chi^{2} \\
\text { prob. }\end{array}$ & $\begin{array}{l}\text { Rainy } \\
\text { season }\end{array}$ & $\begin{array}{l}\chi^{2} \\
\text { prob. }\end{array}$ & $\begin{array}{l}\text { Rainy vs. } \\
\text { post-rainy }\end{array}$ & $\begin{array}{l}\chi^{2} \\
\text { prob. }\end{array}$ \\
\hline $\begin{array}{l}\text { Days to } 50 \% \text { emergence } \\
\text { (number) }\end{array}$ & $3^{\mathrm{a}}$ & 0.06 & 0.04 & 0.08 & 0.05 & 0.02 & 0.06 & 0.07 & 0.07 & 6.66 & 0.04 & 11.43 & $<0.001$ & 0.00 & + & 0.97 & 0.33 \\
\hline $\begin{array}{l}\text { Days to } 50 \% \\
\text { flowering (number) }\end{array}$ & $8^{\mathrm{b}}$ & $0.68^{* *}$ & 0.22 & 0.24 & 0.13 & 0.2 & 0.13 & 0.00 & + & 7694.5 & $<0.001$ & 2322.63 & $<0.001$ & 1260.57 & $<0.001$ & 8985.78 & $<0.001$ \\
\hline Leaflet length $(\mathrm{mm})$ & 3 & $6.18^{* *}$ & 2.15 & 1.2 & 0.99 & 1.17 & 0.99 & 0.00 & + & 558.68 & $<0.001$ & 0.06 & 0.81 & 0.00 & + & 617.64 & $<0.001$ \\
\hline Leaflet width (mm) & 3 & $1.55^{* *}$ & 0.56 & $0.6^{*}$ & 0.28 & 0.46 & 0.35 & 0.18 & 0.36 & 169.22 & $<0.001$ & 0.5 & 0.48 & 0.00 & + & 162.64 & $<0.001$ \\
\hline Plant height $(\mathrm{cm})$ & 3 & $1.22^{*}$ & 0.53 & 0.66 & 0.37 & 0.07 & 0.42 & 0.71 & 0.57 & 2222.54 & $<0.001$ & 14.68 & $<0.001$ & 0.00 & + & 1848.73 & $<0.001$ \\
\hline Primary branch (number) & 3 & 0.00 & 0.02 & $0.09^{* *}$ & 0.03 & $0.09^{* *}$ & 0.03 & 0.00 & + & 1.9 & 0.39 & 0.57 & 0.45 & 0.00 & + & 1.35 & 0.25 \\
\hline $\begin{array}{l}\text { Pods per plant (number) } \\
\text { at } 1240^{\circ} \mathrm{Cd}^{\mathrm{c}}\end{array}$ & 3 & $2.16^{*}$ & 0.98 & 1.38 & 0.74 & 1.39 & 0.74 & 0.00 & + & 48.9 & $<0.001$ & 33.93 & $<0.001$ & 0.00 & + & 15.44 & $<0.001$ \\
\hline $\begin{array}{l}\text { Pod length }(\mathrm{mm}) \\
\text { at } 1240^{\circ} \mathrm{Cd}\end{array}$ & 3 & $13.02^{* *}$ & 3.9 & 1.03 & 0.75 & 0.9 & + & 0.13 & 0.79 & 1.81 & 0.18 & 0.00 & + & 0.00 & + & 1.81 & 0.18 \\
\hline $\begin{array}{l}\text { Pod width }(\mathrm{mm}) \\
\text { at } 12400^{\circ} \mathrm{Cd}\end{array}$ & 3 & $0.69^{* *}$ & 0.22 & 0.11 & 0.06 & 0.08 & + & 0.03 & 0.06 & 5.48 & 0.02 & 0.00 & + & 0.00 & + & 5.48 & 0.02 \\
\hline $\begin{array}{l}\text { Seed length }(\mathrm{mm}) \\
\text { at } 12400^{\circ} \mathrm{Cd}\end{array}$ & 3 & $0.96^{* *}$ & 0.31 & 0.16 & 0.09 & 0.16 & + & 0.00 & + & 2.97 & 0.09 & 0.00 & + & 0.00 & + & 2.96 & 0.09 \\
\hline $\begin{array}{l}\text { Seed width }(\mathrm{mm}) \\
\text { at } 12400^{\circ} \mathrm{Cd}\end{array}$ & 3 & $0.09^{*}$ & 0.04 & 0.04 & 0.03 & 0.04 & + & 0.00 & + & 44.75 & $<0.001$ & 0.00 & + & 0.00 & + & 44.28 & $<0.001$ \\
\hline $\begin{array}{l}\text { Pod yield }\left(\mathrm{kg} \mathrm{ha}^{-1}\right) \\
\text { at } 12400^{\circ} \mathrm{Cd}\end{array}$ & 8 & $10233^{*}$ & 4336 & $21937^{* *}$ & 4227 & $13861^{* *}$ & 3986 & $13964^{* *}$ & 4819 & 673 & $<0.001$ & 561 & $<0.001$ & 310 & $<0.001$ & 39 & $<0.001$ \\
\hline $\begin{array}{l}\text { 100-Seed weight (g) } \\
\text { at } 1240{ }^{\circ} \mathrm{Cd}\end{array}$ & 8 & $10.53^{* *}$ & 3.03 & $3.01^{* *}$ & 0.74 & $2.07^{* * *}$ & 0.8 & $1.78^{*}$ & 0.78 & 114.1 & $<0.001$ & 132.17 & $<0.001$ & 11.81 & 0.003 & 6.62 & 0.01 \\
\hline $\begin{array}{l}\text { Shelling percentage } \\
\text { at } 1240{ }^{\circ} \mathrm{Cd}\end{array}$ & 8 & $9.47^{* * *}$ & 3.31 & $12.96^{* * *}$ & 2.23 & $12.77^{* *}$ & 2.75 & $4.74^{* * *}$ & 1.71 & 348.52 & $<0.001$ & 405.42 & $<0.001$ & 200.60 & $<0.001$ & 7.68 & 0.01 \\
\hline $\begin{array}{l}\text { Pods per plant (number) } \\
\text { at } 1470^{\circ} \mathrm{Cd}^{\mathrm{d}}\end{array}$ & 3 & $4.14^{*}$ & 1.85 & 1.87 & 1.12 & 1.87 & + & 0.00 & + & 5.88 & 0.02 & 0.00 & + & 0.00 & + & 5.87 & 0.02 \\
\hline $\begin{array}{l}\text { Pod length }(\mathrm{mm}) \\
\text { at } 1470^{\circ} \mathrm{Cd}\end{array}$ & 3 & $11.64^{* *}$ & 3.36 & 0.84 & 0.43 & 0.00 & + & $1.55^{*}$ & 0.69 & 5.19 & 0.08 & 11.13 & $<0.001$ & 0.00 & + & 0.31 & 0.58 \\
\hline $\begin{array}{l}\text { Pod width }(\mathrm{mm}) \\
\text { at } 14700^{\circ} \mathrm{Cd}\end{array}$ & 3 & $0.80^{* *}$ & 0.24 & $0.13^{* * *}$ & 0.05 & 0.02 & 0.04 & 0.15 & 0.08 & 4.73 & 0.09 & 0.05 & 0.83 & 0.00 & + & 3.4 & 0.07 \\
\hline $\begin{array}{l}\text { Seed length }(\mathrm{mm}) \\
\text { at } 1470{ }^{\circ} \mathrm{Cd}\end{array}$ & 3 & $0.69^{* *}$ & 0.22 & 0.05 & 0.07 & 0.00 & + & 0.05 & 0.07 & 22.53 & $<0.001$ & 8.71 & 0.003 & 0.00 & + & 26.19 & $<0.001$ \\
\hline $\begin{array}{l}\text { Seed width }(\mathrm{mm}) \\
\text { at } 1470^{\circ} \mathrm{Cd}\end{array}$ & 3 & 0.01 & 0.02 & 0.00 & + & 0.00 & + & 0.00 & + & 74.87 & $<0.001$ & 20.68 & $<0.001$ & 0.00 & + & 54.19 & $<0.001$ \\
\hline $\begin{array}{l}\text { Pod yield }\left(\mathrm{kg} \mathrm{ha}^{-1}\right) \\
\text { at } 14700^{\circ} \mathrm{Cd}\end{array}$ & 8 & 9919 & 5371 & $40938^{* *}$ & 7216 & $35686^{* *}$ & 7924 & $14628^{* *}$ & 6869 & 556 & $<0.001$ & 548 & $<0.001$ & 272 & $<0.001$ & 139 & $<0.001$ \\
\hline $\begin{array}{l}\text { 100-Seed weight (g) } \\
\text { at } 14700^{\circ} \mathrm{Cd}\end{array}$ & 8 & $13.63^{* *}$ & 3.8 & $2.2^{* * *}$ & 0.67 & 0.51 & 0.69 & $1.48^{*}$ & 0.74 & 84.22 & $<0.001$ & 45.45 & $<0.001$ & 95.83 & $<0.001$ & 44.23 & $<0.001$ \\
\hline $\begin{array}{l}\text { Shelling percentage } \\
\text { at } 1470^{\circ} \mathrm{Cd}\end{array}$ & 8 & $8.06^{* *}$ & 2.51 & $3.37^{* *}$ & 1.16 & 0.00 & + & $4.93^{* *}$ & 1.57 & 33.4 & $<0.001$ & 66.17 & $<0.001$ & 117.85 & $<0.001$ & 5.96 & 0.02 \\
\hline
\end{tabular}

(+) Not calculated due to low/non-significant value.

a Recorded in two post-rainy and one rainy season.

${ }^{\mathrm{b}}$ Recorded in five post-rainy and three rainy seasons.

c $1240{ }^{\circ} \mathrm{Cd}$ (degree days) is equivalent to 75 days after sowing (DAS) to harvest in the rainy season at ICRISAT, Patancheru, India.

d $1470{ }^{\circ} \mathrm{Cd}$ (degree days) is equivalent to 90 DAS to harvest in the rainy season at ICRISAT, Patancheru, India.

Significant at $p \leq 0.05$

Significant at $p \leq 0.0$ 
REML analysis indicated that the variance component due to genotype was significant for all the traits in all the seasons. The combined analysis indicated that the genotypic variance was significant for all the traits except days to emergence and number of primary branches per plant and seed width and pod yield at $1470{ }^{\circ} \mathrm{Cd}$.

Seasons were significant for all the traits except number of primary branches, pod and seed length at $1240{ }^{\circ} \mathrm{Cd}$, and pod length and width at $1470{ }^{\circ} \mathrm{Cd}$. The differences between the rainy seasons were significant for days to flower, and at both the harvests $\left(1240{ }^{\circ} \mathrm{Cd}\right.$ and $\left.1470{ }^{\circ} \mathrm{Cd}\right)$ for pod yield, shelling percentage, and 100-seed weight. Post-rainy seasons were significant for days to emergence and flowering, plant height, number of pods per plant, pod yield, shelling percentage, and 100 -seed weight at $1240{ }^{\circ} \mathrm{Cd}$ and for pod length, seed length and width, pod yield, shelling percentage, and 100 -seed weight at $1470{ }^{\circ} \mathrm{Cd}$. The rainy versus post-rainy season component was significant for all the traits except emergence, primary branch number, pod length and seed length at $1240{ }^{\circ} \mathrm{Cd}$, and for pod length and width at $1470{ }^{\circ} \mathrm{Cd}$. The genotype $\times$ season interactions were significant for leaflet width, number of primary branches, pod yield, shelling percentage, and 100-seed weight at both the harvests and for pod width at $1470{ }^{\circ} \mathrm{Cd}$
(Table 4). The genotype $\times$ rainy season interactions were significant for pod yield, 100-seed weight, and shelling percentage at both the harvests; and for pod length at $1470{ }^{\circ} \mathrm{Cd}$ only. The genotype $\times$ post-rainy season interactions were significant for primary branches, and pod yield at both the harvests; and for shelling percentage and 100-seed weight at $1240{ }^{\circ} \mathrm{Cd}$ only.

For the seven yield and yield-component traits, significance of the harvest date was determined. Several traits were significant at the both the harvest dates. They include days to $50 \%$ flowering $(p<0.001)$, pods per plant at $1240{ }^{\circ} \mathrm{Cd}(p<0.001)$ and at $1470{ }^{\circ} \mathrm{Cd}(p=0.015)$, pod width at $1240{ }^{\circ} \mathrm{Cd}(p=0.019)$, seed width at $1240{ }^{\circ} \mathrm{Cd}$ $(p<0.001)$ and at $1470{ }^{\circ} \mathrm{Cd}(p<0.001)$, pod yield $\left(\mathrm{kg} \mathrm{ha}^{-1}\right)$ at $1240{ }^{\circ} \mathrm{Cd}(p<0.001)$ and at $1470{ }^{\circ} \mathrm{Cd}$ $(p<0.001), 100$-seed weight at $1240^{\circ} \mathrm{Cd}(p<0.001)$ and at $1470{ }^{\circ} \mathrm{Cd}(p<0.001)$, shelling percentage at $1240{ }^{\circ} \mathrm{Cd}(p=0.006)$ and at $1470{ }^{\circ} \mathrm{Cd}(p=0.015)$.

The mean pod yield, shelling percentage, and 100-seed weight averaged over three rainy and five post-rainy seasons are presented separately at two harvesting dates $\left(1240{ }^{\circ} \mathrm{Cd}\right.$ and $1470{ }^{\circ} \mathrm{Cd}$ ), along with oil and protein contents in seed (Table 5). All the landraces showed higher values for all the three traits at $1470{ }^{\circ} \mathrm{Cd}$ compared to those at $1240{ }^{\circ} \mathrm{Cd}$. The

Table 5

Mean values for yield and yield components and quality characteristics in early maturity groundnut landraces at two harvesting dates averaged over three rainy and five post-rainy seasons at ICRISAT Center, Patancheru, India

\begin{tabular}{|c|c|c|c|c|c|c|c|c|}
\hline \multirow[t]{2}{*}{ Landrace } & \multicolumn{3}{|l|}{$1240^{\circ} \mathrm{Cd}$} & \multicolumn{5}{|l|}{$1470^{\circ} \mathrm{Cd}$} \\
\hline & $\begin{array}{l}\text { Pod yield } \\
\left(\mathrm{kg} \mathrm{ha}^{-1}\right)\end{array}$ & Shelling\% & $\begin{array}{l}\text { 100-Seed } \\
\text { weight }(\mathrm{g})\end{array}$ & $\begin{array}{l}\text { Pod yield } \\
\left(\mathrm{kg} \mathrm{ha}^{-1}\right)\end{array}$ & Shelling\% & $\begin{array}{l}\text { 100-Seed } \\
\text { weight (g) }\end{array}$ & $\mathrm{Oil}^{\mathrm{a}}$ & Protein $\%^{\mathrm{b}}$ \\
\hline ICG 3200 & 1131.6 & 52.1 & 33.5 & 1570.8 & 64.3 & 42.2 & 48.6 & 25.0 \\
\hline ICG 3540 & 1262.8 & 59.2 & 27.3 & 1455.7 & 68.7 & 31.3 & 48.6 & 24.0 \\
\hline ICG 3631 & 1188.9 & 59.8 & 30.0 & 1496.7 & 67.5 & 33.0 & 47.8 & 24.0 \\
\hline ICG 4558 & 1192.5 & 61.5 & 35.5 & 1380.4 & 66.0 & 40.5 & 47.1 & 24.0 \\
\hline ICG 4729 & 1099.0 & 54.1 & 25.4 & 1429.7 & 67.6 & 29.6 & 47.0 & 23.0 \\
\hline ICG 4890 & 1040.7 & 55.6 & 29.5 & 1499.5 & 67.0 & 36.4 & 48.7 & 23.0 \\
\hline ICG 5512 & 1036.7 & 56.8 & 27.2 & 1410.3 & 67.6 & 32.7 & 48.4 & 23.0 \\
\hline ICG 5560 & 1146.3 & 57.5 & 27.0 & 1491.9 & 69.2 & 32.6 & 47.9 & 23.0 \\
\hline ICG 5881 & 1026.2 & 58.8 & 25.0 & 1442.8 & 68.4 & 30.2 & 48.7 & 23.0 \\
\hline ICG 9427 & 1184.5 & 57.9 & 33.2 & 1645.1 & 69.3 & 40.6 & 47.4 & 24.0 \\
\hline ICG 9930 & 1125.1 & 57.2 & 33.5 & 1419.5 & 65.8 & 37.4 & 47.2 & 23.0 \\
\hline ICG 9968 & 847.3 & 51.8 & 25.5 & 1313.5 & 62.4 & 33.5 & 48.5 & 23.0 \\
\hline ICG 11605 & 979.7 & 50.1 & 27.4 & 1223.6 & 59.4 & 34.6 & 46.6 & 25.0 \\
\hline ICG 11914 & 1037.9 & 50.5 & 28.5 & 1409.0 & 63.3 & 37.1 & 46.8 & 23.0 \\
\hline ICG 13585 & 1072.5 & 56.4 & 30.3 & 1530.9 & 68.0 & 36.5 & 47.2 & 24.0 \\
\hline ICG 13606 & 914.0 & 61.4 & 26.0 & 1379.0 & 71.2 & 29.8 & 46.8 & 23.0 \\
\hline ICG 13647 & 1022.7 & 57.6 & 29.6 & 1479.9 & 67.8 & 35.1 & 47.8 & 23.0 \\
\hline ICG 14390 & 1005.5 & 57.0 & 25.2 & 1391.8 & 68.8 & 31.2 & 48.5 & 22.0 \\
\hline ICG 14788 & 1063.6 & 58.8 & 31.7 & 1493.9 & 69.0 & 37.9 & 47.3 & 23.0 \\
\hline ICG 14814 & 1148.3 & 62.6 & 32.0 & 1460.8 & 71.7 & 36.8 & 47.2 & 24.0 \\
\hline ICG 14815 & 1203.9 & 53.1 & 36.5 & 1627.7 & 61.0 & 45.2 & 45.3 & 26.0 \\
\hline \multicolumn{9}{|l|}{ Controls } \\
\hline Chico & 1031.2 & 62.9 & 28.5 & 1315.9 & 71.3 & 33.4 & 46.4 & 25.0 \\
\hline JL 24 & 987.2 & 54.0 & 30.6 & 1400.2 & 64.5 & 38.1 & 46.4 & 26.0 \\
\hline Gangapuri & 975.8 & 56.6 & 35.9 & 1161.0 & 66.1 & 38.3 & 46.9 & 24.0 \\
\hline Grand mean & 1071.8 & 56.8 & 29.8 & 1434.6 & 66.9 & 35.6 & 47.5 & 23.8 \\
\hline
\end{tabular}

${ }^{a}$ Mean of three seasons data.

b One season data (2001-2002 post-rainy). 
Table 6

Significant correlation coefficients observed in three seasons in the early maturing groundnut landraces at ICRISAT Center, Patancheru, India

\begin{tabular}{|c|c|c|c|c|}
\hline Traits & $\begin{array}{l}1999-2000 \\
\text { post-rainy }\end{array}$ & $\begin{array}{l}2000 \\
\text { rainy }\end{array}$ & $\begin{array}{l}2000-2001 \\
\text { post-rainy }\end{array}$ & $\begin{array}{l}\text { Combined } \\
\text { analysis }\end{array}$ \\
\hline Leaflet length-leaflet width & 0.890 & 0.560 & 0.770 & 0.760 \\
\hline Pod length at $1240^{\circ} \mathrm{Cd}$-pod width at $1240^{\circ} \mathrm{Cd}$ & 0.800 & 0.770 & 0.710 & 0.250 \\
\hline Pod length at $1240{ }^{\circ} \mathrm{Cd}$-seed length at $1240{ }^{\circ} \mathrm{Cd}$ & 0.850 & 0.810 & 0.790 & 0.800 \\
\hline Pod width at $1240{ }^{\circ} \mathrm{Cd}-100$-seed weight $(\mathrm{g})$ at $1240{ }^{\circ} \mathrm{Cd}$ & 0.610 & 0.530 & 0.570 & 0.560 \\
\hline Pod width at $1240{ }^{\circ} \mathrm{Cd}$-seed length at $1240{ }^{\circ} \mathrm{Cd}$ & 0.640 & 0.590 & 0.740 & 0.650 \\
\hline 100 -Seed weight $(\mathrm{g})$ at $1240^{\circ} \mathrm{Cd}$-seed length at $1240^{\circ} \mathrm{Cd}$ & 0.630 & 0.650 & 0.740 & 0.680 \\
\hline Seed width $(\mathrm{g})$ at $1240{ }^{\circ} \mathrm{Cd}$-seed length at $1240{ }^{\circ} \mathrm{Cd}$ & 0.620 & 0.650 & 0.550 & 0.620 \\
\hline Seed width (g) at $1240{ }^{\circ} \mathrm{Cd}-100$-seed weight $(\mathrm{g})$ at $1240{ }^{\circ} \mathrm{Cd}$ & 0.630 & 0.670 & 0.730 & 0.670 \\
\hline Pod length at $1470{ }^{\circ} \mathrm{Cd}$-pod per plant at $1470^{\circ} \mathrm{Cd}$ & -0.650 & -0.820 & -0.750 & -0.750 \\
\hline Pod length at $1470{ }^{\circ} \mathrm{Cd}$-pod width at $1470{ }^{\circ} \mathrm{Cd}$ & 0.680 & 0.705 & 0.750 & 0.430 \\
\hline Pod length at $1470{ }^{\circ} \mathrm{Cd}-$ seed length at $1470{ }^{\circ} \mathrm{Cd}$ & 0.690 & 0.640 & 0.610 & 0.640 \\
\hline Pod width at $1470{ }^{\circ} \mathrm{Cd}$-pod per plant at $14700^{\circ} \mathrm{Cd}$ & -0.570 & -0.690 & -0.540 & -0.610 \\
\hline Pod width at $1470{ }^{\circ} \mathrm{Cd}$-seed length at $1470^{\circ} \mathrm{Cd}$ & 0.620 & 0.510 & 0.730 & 0.620 \\
\hline 100 -Seed weight $(\mathrm{g})$ at $1470{ }^{\circ} \mathrm{Cd}$-seed length at $1470{ }^{\circ} \mathrm{Cd}$ & 0.590 & 0.610 & 0.550 & 0.570 \\
\hline Pod yield $\left(\mathrm{kg} \mathrm{ha}^{-1}\right)$ at $1470{ }^{\circ} \mathrm{Cd}-100$-seed weight $(\mathrm{g})$ at $1470{ }^{\circ} \mathrm{Cd}$ & 0.827 & 0.876 & 0.824 & 0.890 \\
\hline
\end{tabular}

trial mean pod yield at $1470{ }^{\circ} \mathrm{Cd}$ was higher $\left(1435 \mathrm{~kg} \mathrm{ha}^{-1}\right)$ compared to that at $1240{ }^{\circ} \mathrm{Cd}\left(1072 \mathrm{~kg} \mathrm{ha}^{-1}\right)$. The test entries produced an average pod yield of $1082 \mathrm{~kg} \mathrm{ha}^{-1}$, $8.4 \%$ more than the average yield of three control cultivars $\left(998 \mathrm{~kg} \mathrm{ha}^{-1}\right)$ across the eight seasons at $1240{ }^{\circ} \mathrm{Cd}$. At $1470{ }^{\circ} \mathrm{Cd}$, they produced $1455 \mathrm{~kg} \mathrm{ha}^{-1}, 12.6 \%$ more pod yield than the average of three controls $\left(1292 \mathrm{~kg} \mathrm{ha}^{-1}\right)$. The mean pod yields at $1240{ }^{\circ} \mathrm{Cd}$, ranged from $847 \mathrm{~kg} \mathrm{ha}^{-1}$ to $1263 \mathrm{~kg} \mathrm{ha}^{-1}$. Among the controls, Chico gave highest pod yield $\left(1031 \mathrm{~kg} \mathrm{ha}^{-1}\right)$ and shelling percentage $(62.9 \%)$ at $1240{ }^{\circ} \mathrm{Cd}$. Two new early maturity sources, ICG 3540 with $1263 \mathrm{~kg} \mathrm{ha}^{-1}$ (22.5\% higher over Chico), and ICG 14815 with $1204 \mathrm{~kg} \mathrm{ha}^{-1}$ (16.8\% higher over Chico) had superior pod yields, but their shelling percentage was lower compared to that of Chico. However, two other new sources, ICG 4558 with $1193 \mathrm{~kg} \mathrm{ha}^{-1}$ pod yield (15.7\% higher over Chico) and ICG 14814 with $1148 \mathrm{~kg} \mathrm{ha}^{-1}$ (11.4\% higher over Chico) had higher pod yield and similar shelling percentage to that of Chico. Two new sources, ICG 14815 and ICG 4558, were similar in their 100-seed weight to that of the superior control, Gangapuri. The mean pod yields harvested at $1470{ }^{\circ} \mathrm{Cd}$, ranged across the landraces from $1224 \mathrm{~kg} \mathrm{ha}^{-1}$ to $1645 \mathrm{~kg} \mathrm{ha}^{-1}$. Among the controls, JL 24 gave the highest pod yield $\left(1400 \mathrm{~kg} \mathrm{ha}^{-1}\right)$. Several new germplasm landraces gave better pod yield than JL 24. They include, ICG 9427 and ICG 14815, with $17.5 \%$ and $16.3 \%$ increased pod yield, respectively, over JL 24. ICG 14814 and ICG 13606 , with $71.7 \%$ and $71.2 \%$ shelling percentage, respectively, were similar to the best control, Chico $(71.3 \%)$. ICG 14815 and ICG 3200 showed $18.0 \%$ and $10.2 \%$ higher 100-seed weight, respectively, over the best control, Gangapuri $\left(38.3 \mathrm{~g} 100 \mathrm{seed}^{-1}\right)$. Oil and protein contents were similar in the landraces and control varieties.

Correlation coefficients were calculated for all the traits from the observations made in all the seasons separately, on combined data for three rainy, five post-rainy seasons, and on all the eight seasons. A large number of correlations were significant. Of the 276 correlations, studied for various traits,
70 and 37 correlations during 1999-2000 post-rainy season, 98 and 56 correlations during 2000 rainy season, 105 and 52 correlations during 2000-2001 post-rainy season were significant at $5 \%$ and $1 \%$ probability, respectively. Fifteen correlations were significant in the 2000 rainy, 1999-2000 post-rainy, and 2000-2001 post-rainy seasons, and overall (Table 6). Correlation between pod yield and 100-seed weight was significant in all the eight seasons separately, over three rainy seasons, five post-rainy seasons, and over eight seasons at $1470{ }^{\circ} \mathrm{Cd}$.

We have considered correlation coefficients values $\geq 0.71$ or $\leq-0.71$ to be biologically meaningful $\left(R^{2}=0.50\right)$ (Skinner et al., 1999) for selected traits at both the harvesting dates, with the main purpose of minimizing the observations to be recorded, without sacrificing the required information. For almost all the yield traits meaningful correlations with the $R^{2}$ values higher than $50 \%$ were found between the two dates of harvest. However, for pod yield the $R^{2}$ was only $46 \%$ (data not shown). The relationship for 100-seed weight at both the harvesting dates was consistent across both rainy and post-rainy seasons.

The grouping of similar genotypes depends on the dissimilarity among them, which can be determined by a phenotypic diversity index. The average phenotypic diversity index in the early maturity landraces was 0.2941 (Table 7). The closest genotypes with minimum phenotypic diversity in the study were ICG 5512 and ICG 5560 and the farthest genotypes with maximum phenotypic diversity were ICG 13606 (from Indonesia) and ICG 14815 (from

Table 7

Phenotypic diversity index in the early maturity groundnut landraces at ICRISAT Center, Patancheru, India

\begin{tabular}{ll}
\hline Mean phenotypic diversity index & 0.2941 \\
Minimum phenotypic diversity index & 0.1255 \\
Between & ICG 5512 and ICG 5560 \\
Maximum phenotypic diversity index & 0.5291 \\
Between & ICG 13606 and ICG 14815
\end{tabular}




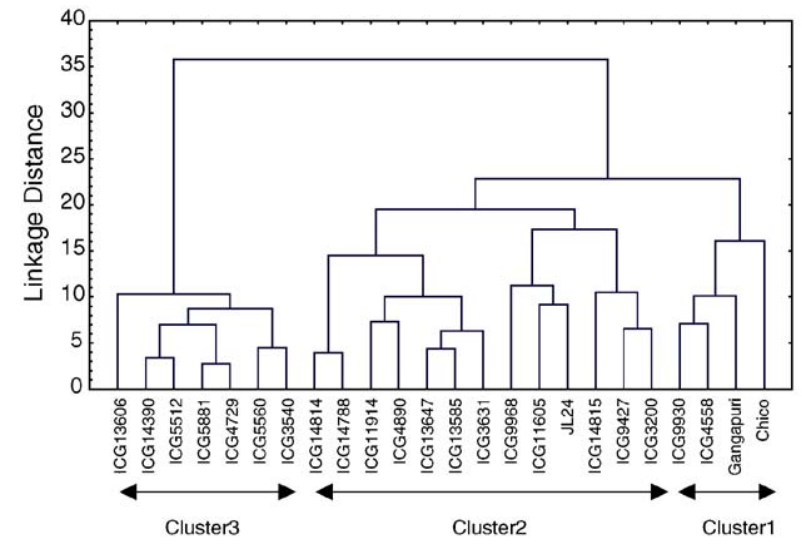

Fig. 1. Dendogram of 21 early maturing groundnut landraces with three control varieties based on the first 10 principal components.

Vietnam). None of the three early maturity controls are captured in either of the minimum or maximum diversity groups. These observations corroborate the presence of additional diversity in the newly identified sources, which is not apparent in the currently used early maturity sources in the breeding programs. It will be interesting to involve the two new genotypes with maximum phenotypic diversity index in the hybridization and selection programs for various traits.

A hierarchical cluster analysis conducted on the first 10 principal component scores (total variation accounted $85.55 \%$ ) resulted in three clusters (Fig. 1). The first cluster comprised two landraces (ICG 9930 and ICG 4558) and the two controls (Gangapuri and Chico). Except for Chico, which belongs to variety vulgaris, the other three belong to variety fastigiata. ICG 4558 is from India and ICG 9930 from Zimbabwe. The second cluster comprised 12 landraces and the control variety, JL 24 from India. Of the 12 landraces, 10 belong to variety vulgaris, with their origins in Vietnam (3), Indonesia (2), Mali, Zaire, Senegal, Sudan, and China (1) accession from each. The remaining two landraces belong to variety fastigiata, one each from Bolivia and Argentina. The third cluster comprised seven landraces of variety vulgaris, three from India, two from China, and one each from Myanmar and Indonesia. The apparent nonrelationship of the origins of these landraces with the diversity available among them is not surprising, if we look at dissemination routes from the center of origin of groundnut to the old world countries. According to Dubard (1906) primarily two distinct groundnut types, the twoseeded Brazilian and the three-seeded Peruvian types, were distributed over the world from South America. Based on the morphology and configuration of pod samples collected from these places and the groundnut samples found in the tombs at Ancon, Peru, Dubard (1906) concluded that the three-seeded Peruvian type (hirsuta) was transported from Peru to the Western Pacific, to China, Java (Indonesia) and to Madagascar (Malagasy Republic, East Africa). Further, Krapovickas (1968) concluded that the Peruvian type reached India from the west coast of South America to Mexico and then across the Pacific to the Philippines, from where it has spread to China, India, Malaysia, and Indonesia. The Portuguese probably brought groundnut to Africa from Brazil in the sixteenth century (Higgins, 1951) and again the reformed varieties from the Old World have been brought to Africa (Krapovickas, 1968).

At a macro-level, involving 13,342 groundnut accessions from 92 countries (grouped into 14 broad geographic regions), a study of 16 morphological and 10 agronomic traits resulted in distinct clusters in tandem with each geographic region (Upadhyaya et al., 2002). In the present study at a micro-level, involving germplasm from few countries, no distinct relationship was observed between country of origin and cluster formation. At the micro-level, the diversity observed in the landraces appears to be small and of nascent origin in the agro-ecologically similar habitats. The adaptation of cultivars can vary with the different environments within a country, and the distribution of local cultivars may to some extent represent their adaptation to the areas in which they are grown (Gibbons, 1978). For example, Harkness et al. (1976) have surveyed the range of local cultivars in northern Nigeria, while others have correlated this with the vegetation, soil, and rainfall (Kowal and Knabe, 1972). Hence, the clustering in the present study could not have captured the country-based landraces due to the possible adaptation of early maturity genotypes in similar ecological niches across the geographical boundaries of their secondary homes.

The means and variances of the three clusters were compared for different traits (Table 8). The clusters did not differ significantly for days to emergence, plant height, primary branches, and seed width, pod yield and shelling percentage at $1240{ }^{\circ} \mathrm{Cd}$. Also, the clusters did not differ for seed width, shelling percentage, oil, and protein content at $1470{ }^{\circ} \mathrm{Cd}$. Clusters 1 and 2 were similar for days to flowering, leaflet length and width and pods per plant, but greater than those in cluster 3 . Cluster 1 had more pods per plant at $1470{ }^{\circ} \mathrm{Cd}$ than cluster 2 or 3 . Clusters 2 and 3 were similar, but were greater than cluster 1 for pod width at $1240{ }^{\circ} \mathrm{Cd}$ and for pod width and seed length at $1470{ }^{\circ} \mathrm{Cd}$. Cluster 3 had greater pod length and seed length at $1240{ }^{\circ} \mathrm{Cd}$ and pod length at $1470{ }^{\circ} \mathrm{Cd}$ than cluster 1 or 2 . The variances of all the three clusters were homogeneous for all the traits, except pods per plant at $1240{ }^{\circ} \mathrm{Cd}$ and $1470{ }^{\circ} \mathrm{Cd}$ and pod width at $1470{ }^{\circ} \mathrm{Cd}$. Cluster 3 had maximum variance for these three traits (Table 8). Cluster 2 represented highest range of entire set for 18 traits, whereas cluster 3 represented the highest range for the remaining 6 traits. The landraces in cluster 2, with a wider range for several traits (such as days to flowering, number of primary branches, pod and seed length at $1240{ }^{\circ} \mathrm{Cd}$ and $1470{ }^{\circ} \mathrm{Cd}$, seed width and pod yield at $1470{ }^{\circ} \mathrm{Cd}$ ), can be selectively deployed in breeding programs aimed at improving either one or more of these traits. Similarly, the landraces in cluster 3 can be used to improve early flowering, pod width, pod length, seed length, 
Table 8

Range, mean, and variance of three clusters of groundnut landraces at ICRISAT Center, Patancheru, India

\begin{tabular}{|c|c|c|c|c|c|c|c|c|c|c|c|}
\hline \multirow[t]{2}{*}{ Character } & \multicolumn{3}{|l|}{ Range } & \multicolumn{3}{|l|}{ Mean $^{1}$} & \multicolumn{5}{|l|}{ Variance } \\
\hline & Cluster 1 & Cluster 2 & Cluster 3 & Cluster 1 & Cluster 2 & Cluster 3 & Cluster 1 & Cluster 2 & Cluster 3 & $F$ value & Prob $>F$ \\
\hline $\begin{array}{l}\text { Days to } 50 \% \\
\text { emergence (number) }\end{array}$ & $8.78-8.99$ & $8.42-9.14$ & $8.49-8.90$ & $8.86 \mathrm{a}$ & $8.82 \mathrm{a}$ & $8.61 \mathrm{a}$ & 0.01 & 0.05 & 0.04 & 1.95 & 0.167 \\
\hline $\begin{array}{l}\text { Days to } 50 \% \\
\text { flowering (number) }\end{array}$ & $39.17-40.86$ & $39.14-41.13$ & $38.25-38.67$ & $40.06 \mathrm{a}$ & $40.24 \mathrm{a}$ & $38.49 \mathrm{~b}$ & 0.30 & 0.34 & 0.03 & 1.12 & 0.345 \\
\hline Leaflet length (mm) & $48.61-53.37$ & $48.11-53.11$ & $45.85-50.56$ & $51.23 \mathrm{a}$ & $50.75 \mathrm{ba}$ & $48.73 b$ & 2.66 & 3.03 & 4.12 & 0.12 & 0.884 \\
\hline Leaflet width $(\mathrm{mm})$ & $22.01-24.53$ & $21.32-25.26$ & $20.93-22.06$ & $23.26 \mathrm{a}$ & $23.31 \mathrm{a}$ & $21.57 \mathrm{~b}$ & 0.63 & 1.02 & 0.26 & 0.83 & 0.449 \\
\hline Plant height (cm) & $16.34-17.96$ & $14.66-18.86$ & $15.49-17.96$ & $17.16 \mathrm{a}$ & $16.62 \mathrm{a}$ & $17.07 \mathrm{a}$ & 0.28 & 1.19 & 1.19 & 0.97 & 0.396 \\
\hline Primary branch (number) & $4.08-4.23$ & $4.04-4.28$ & $4.03-4.14$ & $4.14 \mathrm{a}$ & $4.11 \mathrm{a}$ & $4.08 \mathrm{a}$ & 0.00 & 0.00 & 0.00 & 0.24 & 0.785 \\
\hline $\begin{array}{l}\text { Pods per plant } \\
\quad \text { (number) at } 1240{ }^{\circ} \mathrm{Cd}\end{array}$ & $10.59-13.07$ & $9.50-12.12$ & $8.84-12.63$ & $12.02 \mathrm{a}$ & $10.84 \mathrm{ba}$ & $10.39 \mathrm{~b}$ & 0.71 & 0.81 & 3.06 & 4.53 & 0.023 \\
\hline $\begin{array}{l}\text { Pod length }(\mathrm{mm}) \\
\text { at } 1240{ }^{\circ} \mathrm{Cd}\end{array}$ & $21.43-23.33$ & $21.23-30.47$ & $26.56-33.69$ & $22.55 c$ & $26.03 b$ & $30.66 \mathrm{a}$ & 0.43 & 7.13 & 8.97 & 2.45 & 0.111 \\
\hline $\begin{array}{l}\text { Pod width }(\mathrm{mm}) \\
\text { at } 1240^{\circ} \mathrm{Cd}\end{array}$ & $10.33-11.57$ & $11.00-12.91$ & $10.24-12.62$ & $10.88 \mathrm{~b}$ & $11.90 \mathrm{a}$ & $11.92 \mathrm{a}$ & 0.22 & 0.37 & 1.27 & 2.71 & 0.090 \\
\hline $\begin{array}{l}\text { Seed length }(\mathrm{mm}) \\
\text { at } 1240{ }^{\circ} \mathrm{Cd}\end{array}$ & $9.46-10.49$ & $9.68-12.43$ & $11.62-12.97$ & $10.07 \mathrm{c}$ & $11.40 \mathrm{~b}$ & $12.33 \mathrm{a}$ & 0.12 & 0.52 & 0.47 & 0.85 & 0.442 \\
\hline $\begin{array}{l}\text { Seed width }(\mathrm{mm}) \\
\text { at } 1240{ }^{\circ} \mathrm{Cd}\end{array}$ & $6.77-7.08$ & $6.58-7.47$ & $6.52-7.44$ & $6.91 \mathrm{a}$ & $7.17 \mathrm{a}$ & $7.14 \mathrm{a}$ & 0.01 & 0.06 & 0.18 & 2.03 & 0.156 \\
\hline $\begin{array}{l}\text { Pod yield }\left(\mathrm{kg} \mathrm{ha}^{-1}\right) \\
\text { at } 1240{ }^{\circ} \mathrm{Cd}\end{array}$ & $914.02-1262.81$ & $847.27-1203.95$ & $975.84-1192.53$ & $1070.09 \mathrm{a}$ & $1069.91 \mathrm{a}$ & $1081.16 \mathrm{a}$ & 12557.36 & 10326.00 & 9309.69 & 0.11 & 0.8955 \\
\hline $\begin{array}{l}100 \text {-Seed weight }(\mathrm{g}) \\
\text { at } 1240{ }^{\circ} \mathrm{Cd}\end{array}$ & $25.01-27.30$ & $25.50-36.51$ & $28.54-35.92$ & $26.17 \mathrm{~b}$ & $30.63 a$ & $33.36 \mathrm{a}$ & 1.00 & 8.05 & 11.43 & 1.43 & 0.2622 \\
\hline $\begin{array}{l}\text { Shelling percentage } \\
\text { at } 1240{ }^{\circ} \mathrm{Cd}\end{array}$ & $54.08-61.42$ & $50.14-62.65$ & $56.60-62.92$ & $57.84 \mathrm{a}$ & $55.41 \mathrm{a}$ & $59.53 \mathrm{a}$ & 5.25 & 14.80 & 9.83 & 1.56 & 0.2345 \\
\hline $\begin{array}{l}\text { Pods per plant (number) } \\
\text { at } 1470{ }^{\circ} \mathrm{Cd}\end{array}$ & $11.91-14.36$ & $9.59-13.10$ & $8.46-14.11$ & $13.03 \mathrm{a}$ & $11.36 \mathrm{~b}$ & $10.37 \mathrm{~b}$ & 0.65 & 1.13 & 6.60 & 4.5 & 0.024 \\
\hline $\begin{array}{l}\text { Pod length }(\mathrm{mm}) \\
\text { at } 14700^{\circ} \mathrm{Cd}\end{array}$ & $21.57-23.64$ & $23.71-30.47$ & $26.84-34.51$ & $22.93 \mathrm{c}$ & $26.44 \mathrm{~b}$ & $31.37 \mathrm{a}$ & 0.41 & 4.71 & 10.45 & 3.3 & 0.070 \\
\hline $\begin{array}{l}\text { Pod width }(\mathrm{mm}) \\
\text { at } 1470{ }^{\circ} \mathrm{Cd}\end{array}$ & $10.69-11.53$ & $11.37-13.57$ & $10.29-13.00$ & $11.23 \mathrm{~b}$ & $12.35 \mathrm{a}$ & $12.16 \mathrm{a}$ & 0.08 & 0.48 & 1.62 & 3.65 & 0.044 \\
\hline $\begin{array}{l}\text { Seed length }(\mathrm{mm}) \\
\text { at } 1470{ }^{\circ} \mathrm{Cd}\end{array}$ & $10.04-11.06$ & $10.55-12.95$ & $11.71-12.78$ & $10.69 \mathrm{~b}$ & $11.56 \mathrm{a}$ & $12.25 \mathrm{a}$ & 0.14 & 0.59 & 0.25 & 2.71 & 0.090 \\
\hline $\begin{array}{l}\text { Seed width }(\mathrm{mm}) \\
\text { at } 1470{ }^{\circ} \mathrm{Cd}\end{array}$ & $7.44-7.50$ & $7.40-7.55$ & $7.39-7.50$ & $7.47 \mathrm{a}$ & $7.48 \mathrm{a}$ & $7.46 \mathrm{a}$ & 0.00 & 0.00 & 0.00 & 1.58 & 0.230 \\
\hline $\begin{array}{l}\text { Pod yield }\left(\mathrm{kg} \mathrm{ha}^{-1}\right) \\
\text { at } 1470{ }^{\circ} \mathrm{Cd}\end{array}$ & $1379.04-1491.86$ & $1223.60-1645.08$ & $1160.99-1419.51$ & $1428.75 \mathrm{ba}$ & $1473.21 \mathrm{a}$ & $1319.21 b$ & 1513.03 & 13784.07 & 12950.77 & 1.43 & 0.2624 \\
\hline $\begin{array}{l}\text { 100-Seed weight }(\mathrm{g}) \\
\text { at } 1470{ }^{\circ} \mathrm{Cd}\end{array}$ & $29.63-32.74$ & $33.01-45.20$ & $33.36-40.45$ & $31.07 \mathrm{~b}$ & $37.45 \mathrm{a}$ & $37.38 \mathrm{a}$ & 1.62 & 12.03 & 8.78 & 1.3 & 0.2945 \\
\hline $\begin{array}{l}\text { Shelling percentage } \\
\text { at } 1470{ }^{\circ} \mathrm{Cd}\end{array}$ & $67.56-71.16$ & $59.43-71.74$ & $65.78-71.26$ & $68.77 \mathrm{a}$ & $65.79 \mathrm{a}$ & $67.28 \mathrm{a}$ & 1.47 & 13.05 & 7.05 & 2.67 & 0.0929 \\
\hline Oil\% at $1470{ }^{\circ} \mathrm{Cd}$ & $46.78-48.65$ & $45.33-48.68$ & $46.38-47.23$ & $47.97 \mathrm{a}$ & $47.34 \mathrm{a}$ & $46.90 \mathrm{a}$ & 0.61 & 0.90 & 0.14 & 1.04 & 0.3722 \\
\hline Protein $\%$ at $14700^{\circ} \mathrm{Cd}$ & $22.00-24.00$ & $23.00-26.00$ & $23.00-25.00$ & $23.00 \mathrm{a}$ & $24.08 \mathrm{a}$ & $24.00 \mathrm{a}$ & 0.33 & 1.24 & 0.67 & 1.91 & 0.1735 \\
\hline
\end{tabular}

${ }^{1}$ For cluster mean followed by same letter indicates no significant difference at $p \leq 0.05$. 
and shelling percentage at $1240{ }^{\circ} \mathrm{Cd}$ and pod length at $1470{ }^{\circ} \mathrm{Cd}$.

With the predicted changes in global temperature and rainfall patterns, it may become necessary to select and match the genotype more carefully to the length of growing season. For instance, groundnut production in Nigeria was reduced over the past few years because of severe droughts. The isohyet movement towards the south has resulted in the shortening of the period of useful rains in the northern Nigeria. This has necessitated the shift from growing longer season groundnut genotypes to shorter season genotypes of 75-90 days duration (Gibbons, 1978). Agroclimatological analysis of major rainfed groundnut environments in the SAT indicate that growing areas in the SAT are characterized by short growing seasons, i.e. 75-110 days (Virmani and Singh, 1986). Hence, the demand for diverse early maturity groundnut varieties suitable for various agroclimatic conditions will be increasingly felt.

From the long-term studies of changes in adaptedness in a number of experimental populations of annual plants that developed under predominant selfing, Allard (1988) found patterns of ecogenetic differentiation characterized by fine-scaled overlays of environmental heterogeneity. The picture of evolutionary change that emerges from this study is one in which the incorporation of increasing number of favorably interacting alleles into large synergistic complexes in the inbreeding populations. Hence, use of germplasm sources that originated under different agro-ecologies provides better opportunities to improve the complex traits such as early maturity in autogamous crops (e.g. groundnut) through recombination breeding. The diverse early maturity sources identified from different countries in the present study are agronomically superior and therefore likely to provide better opportunities in developing early maturity cultivars suitable for different geographic regions. While selecting the exotic germplasm lines for inclusion in the breeding programs, it is important to consider the genetic background and agronomic performance of the lines as it will be useful in predicting their behavior in hybrid combinations with the adapted genotypes. The less divergent the germplasm lines and adapted lines, the more likely it will be that additive gene effects will play a primary role in inheritance of quantitative traits (Isleib and Wynne, 1983). As the diversity between the parents increases, dominance effects and epistatic variations have significant roles in the inheritance of quantitative traits (Halward and Wynne, 1991). In groundnut, a self-pollinated crop, this would have implications in choosing an appropriate selection strategy.

\section{References}

Allard, R.W., 1988. Genetic changes associated with the evolution of adaptedness in cultivated plants and their wild progenitors. J. Hered. $79,225-238$.
Anderson, W.F., Holbrook, C.C., Culbreath, A.K., 1996. Screening the core collection for resistance to tomato spotted wilt virus. Peanut Sci. 23, 57 61.

Bailey, W.K., Hammons, R., 1975. Registration of Chico peanut germplasm. Crop Sci. 15, 105.

Dubard, M., 1906. De l' origine de l' Arachide. Museum of Natural History Naturelle, Paris. Bulletin 5, 340-344.

FAO, 2004. Food and Agriculture Organization of the United Nations. FAOSTAT Database.

Franke, M.D., Brennemen, T.B., Holbrook, C.C., 1999. Identification of resistance to Rhizoctonia limb rot in a core collection of peanut germplasm. Plant Dis. 83, 944-948.

Gibbons, R.W., 1978. Adaptation and utilization of peanuts in different environments and farming systems. In: Summerfield, R.J., Bunting, H. (Eds.), Advances in Legume Sciences. Royal Botanical Gardens, Kew, UK, pp. 483-493.

Gibbons, R.W., 1980. The ICRISAT Groundnut Program. In: Proceedings of International Workshop on Groundnuts, International Crops Research Institute for the Semi-Arid Tropics (ICRISAT), Patancheru, Andhra Pradesh, India, October 13-17, pp. 12-16.

Halward, T.M., Wynne, J.C., 1991. Correlation means analysis for productivity in two diverse peanut crosses. Theor. Appl. Genet. 82, 784-792.

Harkness, C., Kolawole, K.B., Yayock, J.H., 1976. Groundnut research in Nigeria. In: Samaru Conference Paper 7, Zaria, Nigeria.

Higgins, B.B., 1951. Origin and early history of the peanut. In: The Peanut-The Unpredictable Legume, The National Fertilzation Association, Washington, DC, pp. 118-127.

Holbrook, C.C., Bruniard, J., Moore, K.M., Knauft, D.A., 1998. Evaluation of the peanut collection for oil content. In: Agronomy Abstracts, ASA, Madison, WI, p. 159.

Holbrook, C.C., Anderson, W.F., 1995. Evaluation of a core collection to identify resistance to late leaf spot in peanut. Crop Sci. 35, 17001702.

IBPGR and ICRISAT, 1992. Descriptors for Groundnut. International Board for Plant Genetic Resources, Rome, Italy; International Crops Research Institute for the Semi-Arid Tropics, Patancheru, India, pp. 1-125.

Isleib, T.G., Beute, M.K., Rice, P.W., Hollowel, J.E., 1995. Screening the core collection for Cylindrocladium black rot and early leaf spot. Proc. Am. Peanut Res. Educ. Soc. 27, 25.

Isleib, T.G., Wynne, J.C., 1983. Heterosis in test crosses of 27 exotic peanut cultivars. Crop Sci. 23, 832-841.

Jambunathan, R., Raju, S.M., Barde, P., 1985. Analysis of oil contents of groundnut by nuclear magnetic resonance spectrometry. J. Sci. Food Agric. 36, 162-166.

Johns, M.A., Skroach, P.W., Nienhuis, J., Hinrichsen, P., Bascur, G., MunozSchick, C., 1997. Gene pool classification of common bean landraces from Chile based on RAPD and morphological data. Crop Sci. 37, 605613.

Keuls, M., 1952. The use of the 'studentized range' in connection with an analysis of variance. Euphytica 1, 112-122.

Kowal, J.M., Knabe, D.T., 1972. An Agroclimatological Atlas of the Northern State of Nigeria. Ahmadu Bello University, University Press, Samaru, Zaria.

Krapovickas, A., 1968. Origen, variabilidad y diffusion del mani (Arachis hypogaea) Actas y Memorias, Congress International Americanistas, vol. 2, pp. 517-534, Buenos Aires. Eng. tr., The origin, variability and the spread of the groundnut (Arachis hypogaea). In: Ucko, P.J., Falk, I.S. (Eds.), The Domestication and Exploitation of Plants and Animals. Gerald Duckworth Co. Ltd., London, 1969, pp. 427-441.

Krapovickas, A., Gregory, W.C., 1994. Taxonomia del genero Arachis (Leguminosae). Bonplandia VIII, 1-187.

Levene, H., 1960. Robust tests for equality of variances. In: Olkin, I. (Ed.), Contributions to Probability and Statistics: Essays in Honour of Harold Hotelling. Stanford University Press, Stanford, pp. 278-292.

N'Doye, O., Smith, O.D., 1993. A note on the earliness of offspring from crosses among five short growth duration peanut lines. Peanut Sci. 20, $132-137$. 
Newman, D., 1939. The distribution of range in samples from a normal population expressed in terms of an independent estimate of standard deviation. Biometrika 31, 20-30.

Patil, G.D., Desale, S.C., Patil, P.S., 1980. 'Phule Pragati'. A high yielding early bunch groundnut variety for Maharashtra. J. Maharashtra Agric. Univ. 5, 47-52.

Ramachandran, T.K., Venkateswaran, A.N., Vinai, R., Srinivasan, G., 1980. An assessment of Gangapuri, a valencia groundnut (Arachis hypogaea Linn.) Madras Agric. J. 67, 351-359.

Ramamurthy, G.V., 1974. Improved strains of oilseeds in India and their characteristics (statements). Oilseeds J. 4, 12-33.

Rao, M.J.V., Nigam, S.N., Huda, A.K.S., 1992. The thermal time concept as a selection criterion for earliness in peanut. Peanut Sci. 19, 7-10.

Singh, U., Jambunathan, R., 1980. Evaluation of rapid method for the estimation of protein in chickpea (Cicer arietinum L.) J. Sci. Food Agric. 31, 247-254.

Skinner, D.Z., Bauchan, G.R., Auricht, G., Hughes, S., 1999. A method for the efficient management and utilization of large germplasm collections. Crop Sci. 39, 1237-1242.

Smartt, J., 1994. The Groundnut Crop-A Scientific Basis for Improvement. Chapman and Hall, London, p. 734.

Upadhyaya, H.D., 2005. Variability for drought resistance related traits in the mini core collection of peanut. Crop Sci. 45, 1432-1440.
Upadhyaya, H.D., Bramel, P.J., Ortiz, R., Singh, S., 2002. Geographical patterns of diversity for morphological and agronomic traits in the groundnut germplasm collection. Euphytica 128, 191-204.

Upadhyaya, H.D., Ortiz, R., Bramel, P.J., Singh, S., 2003. Development of a groundnut core collection using taxonomical, geographical and morphological descriptors. Genet. Resour. Crop Evol. 50, 139-148.

Upadhyaya, H.D., Nigam, S.N., Singh, S., 2001a. Evaluation of groundnut core collections to identify sources of tolerance to low temperature at germination. Indian J. Plant Genet. Resour. 14, 165-167.

Upadhyaya, H.D., Nigam, S.N., Singh, S., 2001b. Identification of new sources of early-maturity in groundnut core collection. In: Kharakwal, M.C., Mehra, R.B. (Eds.), Proceedings of the Diamond Jubilee Symposium. Hundred Years of Post-Mendelian Genetics and Plant Breeding-Retrospect and Prospects, Indian Society of Genetics and Plant Breeding, New Delhi, India, November 6-9, pp. 43-44.

Virmani, S.M., Singh, P., 1986. Agroclimatology characteristics of the groundnut regions in the semi-arid tropics. In: Agrometeorology of Groundnut. Proceedings of International Symposium, ICRISAT Sahelian Centre, Niamey, Niger; ICRISAT, Patancheru, Andhra Pradesh, India, pp. 35-46.

Ward, J., 1963. Hierarchical grouping to optimize an objective function. J. Am. Stat. Assoc. 38, 236-244. 